\title{
Surgical treatment of omphalocele with intestinal evisceration in cow calf of Sahiwal: A case report
}

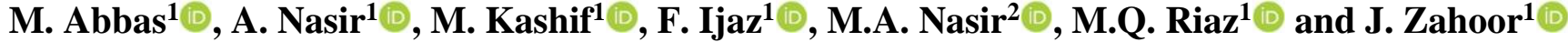 \\ ${ }^{1}$ Department of Clinical Sciences, ${ }^{2}$ Department of Pathobiology, College of Veterinary and Animal Sciences, Punjab, \\ Pakistan
}

\author{
Article information \\ Article history: \\ Received September 9, 2020 \\ Accepted June 19, 2021 \\ Available online October 1, 2021 \\ Keywords: \\ Omphalocele \\ Congenital abnormalities \\ Abdominal rectification \\ Sahiwal calf

\section{Correspondence: \\ M. Abbas \\ mazhar.abbas.me@gmail.com}

\begin{abstract}
Omphalocele is a rare type of congenital abdominal wall defect that allows intestines (and sometimes a portion of liver) covered by a paper-thin membrane (amnion) to protrude from the abdominal wall at the navel area. The aim of the current study is to report the first successful rectification of a congenital omphalocele in a day old neonatal cow calf using a basic suture pattern in laparotomy at cattle populous area of Jhang (Punjab). The case was presented at College of Veterinary and Animal Sciences, Jhang. The calf after surgery manifested a steady and progressive growth rate without any complication suggesting the success of the surgical remedy. At the same time this approach is quite economical to the farmer in the context of saving the life of his farm. It is concluded that this surgery can instituted with success in cases with fair body condition, less contaminated in the absence of predominant necrosis of the tissues.
\end{abstract}

DOI: 10.33899/ijvs.2021.128322.1569, (CAuthors, 2021, College of Veterinary Medicine, University of Mosul.

This is an open access article under the CC BY 4.0 license (http://creativecommons.org/licenses/by/4.0/).

\section{Introduction}

Omphalocele (evisceration of intestine or other organs through umbilical ring), is a congenital defect of closure of abdominal muscles and skin at the site of umbilical ring covered with thin membrane, get ruptured leading to evisceration of abdominal contents. This condition may have genetic ramification. It is a different anomaly than congenital umbilical hernia which is covered from skin. The fold of small intestine, large intestine and sometimes other portions of gastrointestinal tract like liver protrude out of the body (1). These organs are covered by fluid filled transparent amnion membrane instead of skin. Many reasons have linked with congenital abnormalities in animals like environment, genetic disorders, like chromosomal annoyance etc. Some other factors also play important role like toxins, drugs and nutrition (2). The ratio of these congenital abnormalities varies from species to species. In sheep, goat, cattle and buffalo it ranges 2-3:1000 (3). The risk factors includes short time gestation period and multiparous animals (4). Unlike umbilical hernia, this is the most emergency surgery to be performed to save the life of calf (5). This disorder may be caused by improper closing of the umbilical opening at the time of birth or hypoplasia of the abdominal muscle and skin (6). Umblical hernia is more commonly observed in Holstein Friesian calves, according to previous studies. However, it can affect any breed of cattle (7).

\section{Case history}

A day old, male, brown, cow calf of Sahiwal breed weighing $22 \mathrm{Kg}$ was presented at the veterinary teaching hospital, College of Veterinary and Animal Sciences, Jhang one hour after birth with moderate to good body condition. Calving history narrated by the owner was unassisted and normal, but the calf exhibited eviscerated bowel at the level of umbilicus. On clinical examination of physical parameters, a rectal temperature of $101^{\circ} \mathrm{F}$, respiratory rate 28 respirations/min and pulse rate of 112 beat per min were recorded. The amnion membrane around intestines was ruptured and mildly contaminated with manure and bedding material and the farmer had covered it with clean cloth. While the opening of umbilicus ranged between 1.75-2.5 
$\mathrm{cm}$. There was no attachment of umbilical cord with its ring as shown in (Figure 1). After clinical examination the case was diagnosed has omphalocele with intestinal evisceration and was recommended for emergency reconstructive surgery (Herniorrhaphy).

\section{Surgical treatment}

The surgical site at the area of umbilicus around the ring was prepared under aseptic technique (Figure 2). The surgical site was locally desensitized by infiltrating local anesthesia (ring block) Lignocaine ( $\mathrm{HCl}$ ) 2\% (Lawrence Pharma, Pvt. Lahore, Pakistan). The protruding mass of intestine contaminated with manure and other bedding material was flushed using lukewarm normal saline but still there was some dirt attached with intestine. It was not completely removed due to the risk of hemorrhages by rubbing of mass with cotton swabs. Extra skin and amnion membrane were also removed to avoid the hindrance during reduction of bowel to its original site. After washing, the ring was excised to extend the opening of ring so that the bowel mass may be pushed safely (Figure 3). It was extended cranially up to $3 \mathrm{~cm}$ and intestine was lubricated with liquid paraffin to push it gently without any further injury. Now for closing the layers of abdominal wall, following commercial suture materials (Shanghai Medicine and Health Production, China) with described suture pattern were used. Herniorrhaphy, an emergency surgery was performed/undertaken within one hour after the presentation of animal.

Chromic catgut No.2 was used for closing the peritoneum with thin layer of muscle by simple continuous suture pattern and chromic catgut No. 1 used for muscles by horizontal mattress pattern. The skin was sutured using simple interrupted suture pattern through silk breaded No. 1 (Figure 4). Before suturing healthy bright, pinkish color of the eviscerated part peristaltic movement of the bowel were evaluated and ensured to be normal. This was checked after putting intestine in abdominal cavity. Meanwhile, during the surgery temperature, pulse and respiratory rate were recorded at regular interval and were found in normal range. Calf was maintained on fluid therapy with Dextrose Normal Saline (Zeesol-DS, Sahzeb Pharmaceutical Industries, Pakistan) for four days after surgery while from $5^{\text {th }}$ day onward dam suckling was started. Postoperative care of surgical site (antiseptic dressing) was done at regular basis by applying combination of Polyfax Skin Ointment (GlaxoSmithKline, Pakistan) and Procaine Penicillin 40 lac IU. (Yanzhou Xier Kangtai Pharm Co., Ltd., China). On revisit after a week (8th day), the calf was clinically evaluated normal with a temperature, pulse and respiratory rate of $100^{\circ} \mathrm{F}, 122$ beat per min. and $27 / \mathrm{min}$. respectively. The suture line was intact showing gradual skin healing normally.

The calf was feeding well and was in active state. On day 21 , the wound was completely healed without any complication and the calf showed good weight gain, weighing $35 \mathrm{Kg}$. At the $22^{\text {nd }}$ day suture was removed, now the skin at incision site was normal and there was no complication. Calf was passing the feces normally. No gastrointestinal problem was seen during this period.

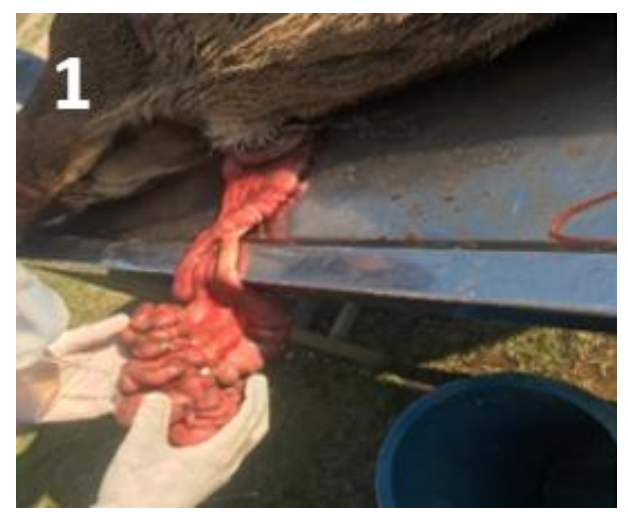

Figure 1: crossbred cow calf with omphalocele.

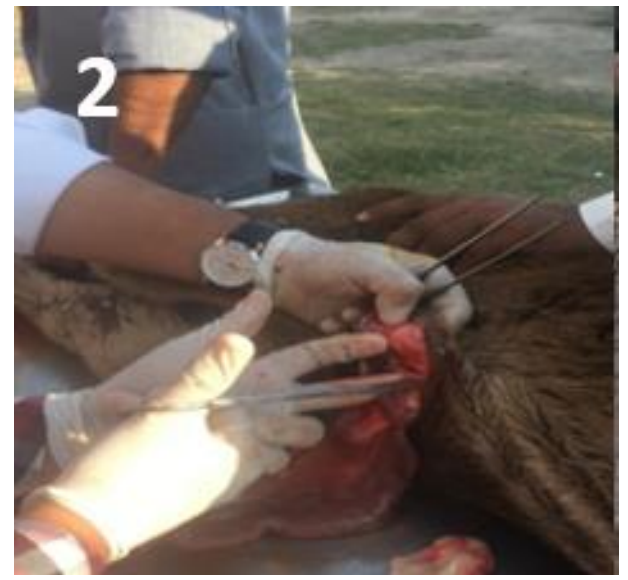

Figure 2: washing and cleaning of protruded mass (bunch of intestine).

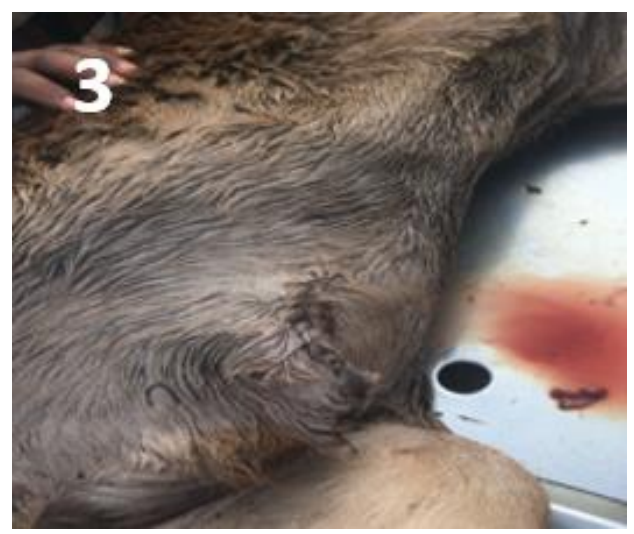

Figure 3: Extension of incision site to place the intestine at the original site. 


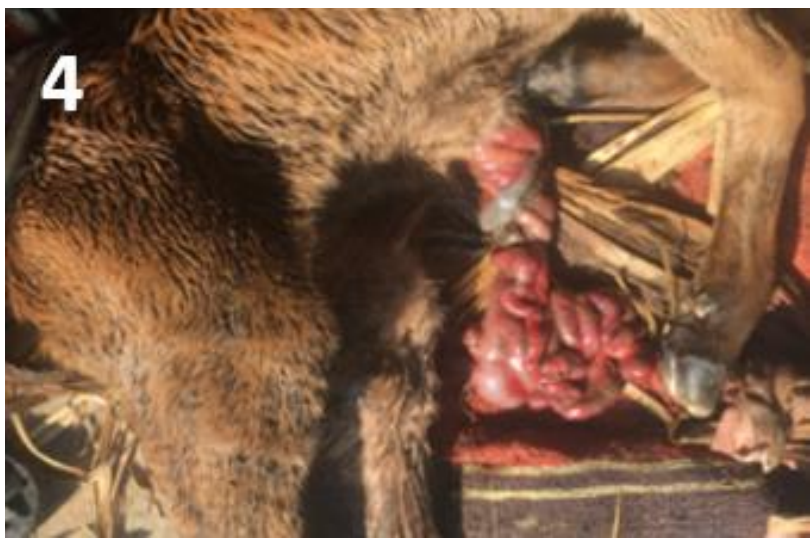

Figure 4: Suturing after completion of insertion of mass.

\section{Discussion}

This was the first report of omphalocele reported in the cow calf from Pakistan. The congenital malformations may prove lethal, partially fatal or cause lifelong abnormalities and also in some cases no effect on animals (4).

In advance stages of life this body wall is contracted and the umbilical ring is contracted to push the intestines back into the abdominal cavity. If the contraction does not occur with intestinal contraction than it causes umbilical hernia (4).

Genetically associated issues like inbreeding and close line breeding increase the risks of such anomalies. Males are more affected with these defects due to their anatomical characteristics which subsequently affects breeding efficiency and secondary sexual characters (5).

The umbilicus in newborn calves consists of the urachus (a tube that attaches the fetal bladder to the placental sac) and the remnants of the umbilical vessels that transport blood between the fetus and its mother. Normally, just after birth these structures shrink until only tiny remnants remain within the abdomen (belly). If the area in the body wall through which these structures passed remains open, abdominal contents can protrude through the defect resulting in an umbilical hernia.

During this process, the growing intestinal loop rotates $180^{\circ}$ clockwise around a dorso-ventral axis with the cranial mesenteric artery located in the axis (citation). Hernia size varies depending on the extent of the umbilical defect and the amount of abdominal contents contained within it.

Umbilical hernias are the most common birth defects in calves, especially in Holstein-Friesians. The etiology of umbilical hernias likely has a genetic component; however, excess traction on an oversized fetus or cutting the umbilical cord too close to the abdominal wall are other possible causes Congenital intestinal prolapse through the persistent umbilical opening in the new born calf and kid has been reported earlier (6).

However, we reported a case of eventration of colon and blind end of rectum through the umbilicus (7). This is similar to the previous reports which stated that, the abomasum with or without omentum was the most common viscera involved in umbilical hernias. At birth, hernia may be small and enlarge with age, and should be distinguished from umbilical sepsis (8).

The majority of these calves had other conditions (enteritis, polyarthritis and pneumonia). It was concluded that this surgery can be instituted with success in cases with fair body condition, less contamination in the absence of predominant necrosis of the tissues. This will help the field practioners to save the life of precious animals and increase the economics of the country as well.

\section{Conclusion}

It was concluded that the being congenital problem in calves, can be treated in field operations successfully. In this case; Omphalocele was responsible for prenatal mortality of kid. If the fetus parturate live with omphalocele; then protruding organs are repossessing in abdominal cavity so, it is surgically curable.

\section{Conflict of interest}

The authors declare that there is no conflict of interest.

\section{References}

1. Lotfi A, Shahryar HA. The case report of taillessness in Iranian female calf: A congenital abnormality. Asian J Anim Vet Adv. 2009;4:47-51. DOI: 10.3923/ajava.2009.47.51

2. Weaver AD, Blowey RW. Color atlas of diseases and disorders of cattle. $3^{\text {rd }}$ ed. New York: Mosby; 1991. 225-350 p.

3. Sutradhar BC, Hossain MF, Das BC, Kim G, Hossain MA. Comparison between open and closed methods of herniorrhaphy in calves affected with umbilical hernia. J Vet. Sci. 2009;10(4):343-347. DOI: $10.4142 /$ jvs.2009.10.4.343

4. Dar $\mathrm{SH}$, Bhattacharyya $\mathrm{H}$. Congenital omphalocele in four calves, their surgical management and outcome. Ind $\mathrm{J}$ Anim Res. 2016;50(5):25-30. DOI: 10.18805/ijar.11168

5. Sagar PV, Vadde K, Krishna KS, Venkateswarlu S. An omphalocele in a buffalo calf: A case report. Buffalo Bulleitn. 2011;30(1):10181022. DOI: $10.6000 / 1927-520 x .2013 .02 .01 .10$

6. Fazili M, Buchoo B, Bhattacharyya H, Khan I. Uncomplicated (simple) umbilical hernia in crossbred dairy calves: Management with or without surgery. Indian Vet J Surg. 2013;34(2):111-114. [availabe at]

7. Amresh K. Surgery of abdomen and organs of digestive system. $1^{\text {st }}$ ed. New York: Mosby; 2009. 310-312 p.

8. Kumar V, Kumar N, Gangwar AK, Saxena AC. Using a cellular aortic matrix to repair umbilical hernias of calves. Aust Vet J. 2013;91(6):251-253. DOI: $\underline{10.1111 / a v j .12058}$ 
الكبد المغطى بغشاء رقيق من السلى من خلال جدار البطن في منطقة

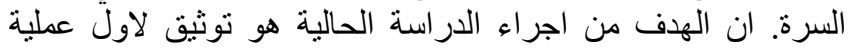

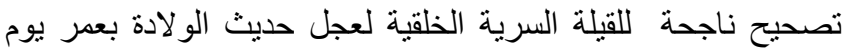
واحد في منطقة التربية المكثفة للابقار في مدينة جانك لإنة (البنجاب)

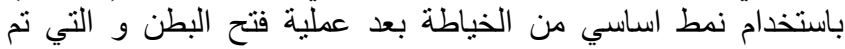

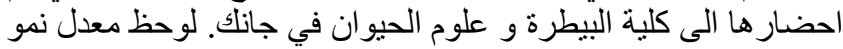

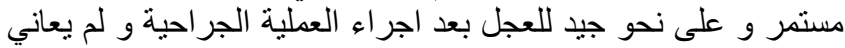

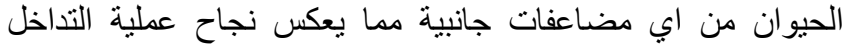

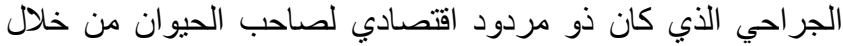
المحافظة ثروته الحيو انية من النفوق. يمكن الاستنتاج بامكانية نجاح

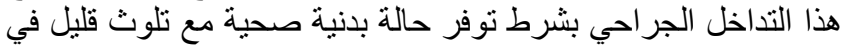
منطقة الخلل بشرط عدم حدوث تنخر الانسجة.
العلاج الجراحي للقيلة السرية مع بروز جزء من من فئ

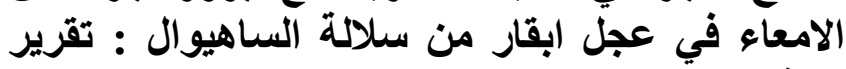
حالة الأعاء

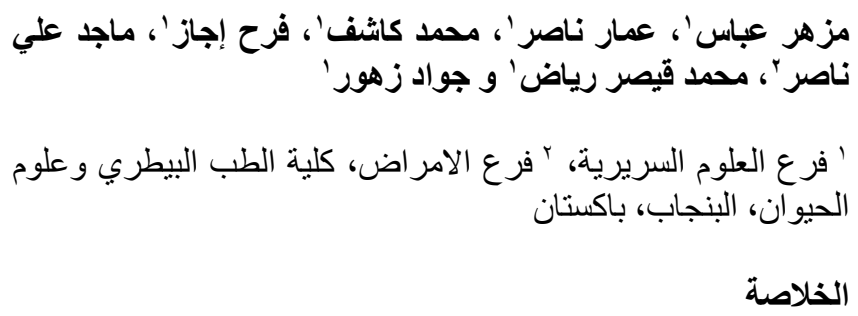

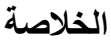

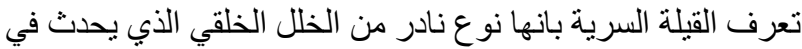

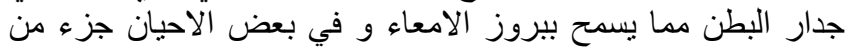

